\title{
Transfemoral TAVI devices: design overview and clinical outcomes
}

Mohamed Abdel-Wahab*, MD, FESC; John Jose, MD, DM (Card); Gert Richardt, MD

Heart Center, Segeberger Kliniken GmbH, Bad Segeberg, Germany

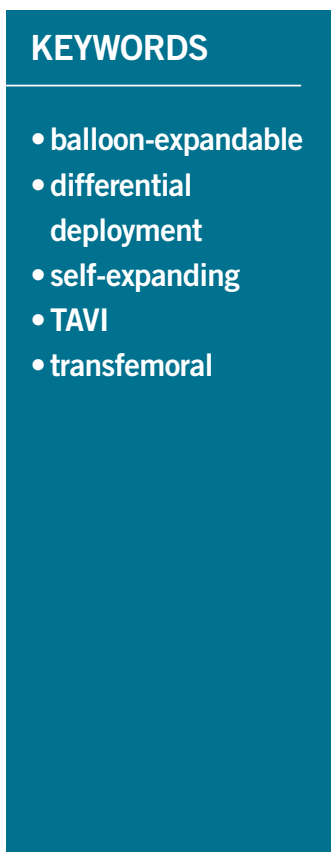

\section{Abstract}

Over the last decade, transcatheter aortic valve implantation (TAVI) has gained widespread acceptance for the treatment of high surgical risk or inoperable patients with severe aortic stenosis. Spurred on by initial success and an ever-growing body of supporting data, TAVI has undergone rapid technological advancements in recent years with a focus on procedural simplification and limiting complications associated with the early devices. In this article, we provide a brief overview of the past, current and newer devices for transfemoral (TF) TAVI and their post-procedural outcomes.

\footnotetext{
*Corresponding author: Heart Center, Segeberger Kliniken GmbH, Am Kurpark 1, 23795 Bad Segeberg, Germany. E-mail: mohamed.abdel-wahab@segebergerkliniken.de
} 


\section{Introduction}

Transcatheter aortic valve implantation (TAVI) has become the new standard of care for high surgical risk or inoperable patients with severe aortic stenosis, affording excellent periprocedural, early and midterm outcomes. The majority of TAVI procedures performed in the initial decade after its introduction in $2002^{1}$ used one of the first-generation devices: the balloon-expandable Edwards SAPIEN and SAPIEN XT (Edwards Lifesciences, Irvine, CA, USA) and the self-expanding CoreValve ${ }^{\circledR}$ (Medtronic, Minneapolis, MN, USA). These devices demonstrated outcomes which were superior to medical therapy and comparable to surgery in randomised trials. However, concerns including procedural complexity, paravalvular regurgitation, valve malpositioning, lack of repositionability and retrievability, neurological complications and conduction disturbances limited the expansion of TAVI to intermediate surgical risk and other population subsets. The favourable outcomes and accompanying limitations observed with the first-generation devices fuelled subsequent rapid innovations and refinements in device designs and delivery system technologies that have resulted in several second-generation devices receiving a CE mark in recent years (Table 1). Several other devices which have been specifically designed to overcome the limitations of first-generation devices are in early clinical evaluation but have not yet received their CE mark. All currently available and newgeneration devices can be broadly grouped based upon their mode

Table 1. Overview of current data on new-generation transfemoral aortic valves.

\begin{tabular}{|c|c|c|}
\hline $\begin{array}{l}\text { Devices and } \\
\text { sizes ( } m m)\end{array}$ & CE mark & Clinical outcomes \\
\hline \multicolumn{3}{|c|}{ Balloon-expandable valves } \\
\hline $\begin{array}{l}\text { SAPIEN } 3 \\
23,26,29\end{array}$ & January 2014 & $\begin{array}{l}3.5 \% \text { moderate AR, } 2.1 \% \text { mortality and no } \\
\text { strokes at } 30 \text { days for transfemoral route. } \\
11.6 \% \text { mortality and } 5.6 \% \text { strokes at } \\
30 \text { days for non-femoral route } 2 \text {. }\end{array}$ \\
\hline \multicolumn{3}{|c|}{ Self-expanding valves } \\
\hline $\begin{array}{l}\text { CoreValve Evolut } \mathrm{R} \\
23,26,29\end{array}$ & $\begin{array}{c}23 \mathrm{~mm} \\
\text { (September 2014) } \\
26,29 \mathrm{~mm} \\
\text { (February 2015) }\end{array}$ & $\begin{array}{l}78.6 \% \text { device success, no deaths or strokes } \\
\text { at } 30 \text { days. } 3.4 \% \text { moderate AR at } 30 \text { days } \\
\text { and } 7.4 \% \text { at } 6 \text { months. Seven patients } \\
(11.7 \%) \text { needed a permanent pacemaker at } \\
30 \text { days } 4 \text {. }\end{array}$ \\
\hline $\begin{array}{l}\text { Portico } \\
23,25 \\
(27,29 \text { in trial })\end{array}$ & November 2012 & $\begin{array}{l}\text { First in-human experience: } 10 \text { patients. One } \\
\text { had moderate AR at } 30 \text { days. No deaths, } \\
\text { major strokes or permanent pacemaker }{ }^{5} \text {. }\end{array}$ \\
\hline $\begin{array}{l}\text { ACURATE neo } \\
\text { Small, medium, } \\
\text { large }\end{array}$ & September 2014 & $\begin{array}{l}4.9 \% \geq \text { moderate } \mathrm{AR}, 3.4 \% \text { mortality, } \\
9 \% \text { new pacemaker rate at } 30 \text { days, } \\
13.5 \% \text { mortality at } 6 \text { months }{ }^{6} \text {. }\end{array}$ \\
\hline $\begin{array}{l}\text { CENTERA } \\
23,26,29\end{array}$ & - & $\begin{array}{l}\text { Feasibility study: } 15 \text { patients. At } 30 \text { days, } \\
\text { one patient had moderate AR, four had } \\
\text { a new permanent pacemaker. } 13 \% 30 \text {-day } \\
\text { mortality and } 20 \% \text { one-year mortality }\end{array}$ \\
\hline \multicolumn{3}{|c|}{ Devices with differentiated deployment technology } \\
\hline $\begin{array}{l}\text { Lotus } \\
23,25,27\end{array}$ & October 2013 & $\begin{array}{l}\text { REPRISE II: } 1.9 \% \geq \text { moderate AR, } \\
1.7 \% \text { mortality at } 30 \text { days, } 29.3 \% \text { new } \\
\text { pacemaker rate }{ }^{9} \text {. }\end{array}$ \\
\hline $\begin{array}{l}\text { Direct Flow } \\
23,25,27,29\end{array}$ & January 2013 & $\begin{array}{l}\text { DISCOVER trial: } 1.4 \% \geq \text { moderate AR, } \\
1 \% \text { mortality at } 30 \text { days }^{10} .\end{array}$ \\
\hline
\end{tabular}

of deployment: balloon-expandable, self-expanding or differential device deployment (the latter two groups being partially or fully repositionable) (Figure 1). In this focused article, we provide an overview of these valve technologies and their recent clinical evidence base when used for TAVI via the transfemoral (TF) route the most frequently used access site for valve implantation.

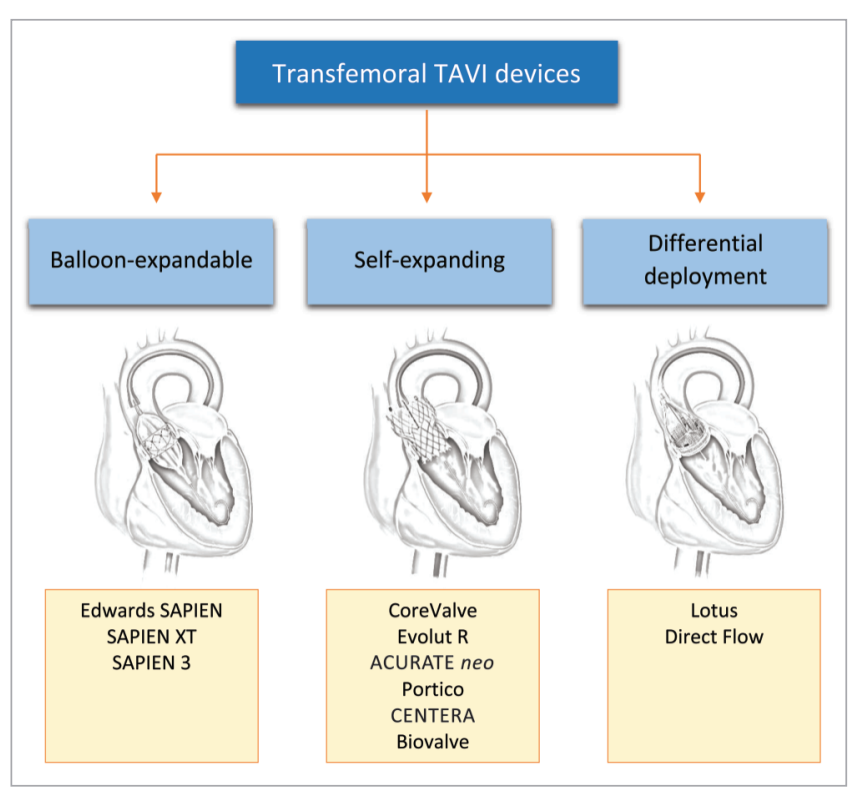

Figure 1. Devices for transfemoral transcatheter aortic valve implantation (TAVI).

\section{Balloon-expandable valves}

Conceptually, all balloon-expandable valves consist of biological cardiac valve tissue sewn inside an expandable stent frame, which is subsequently crimped onto a balloon whose expansion results in valve deployment. Deployment requires rapid ventricular pacing.

\section{THE EDWARDS SAPIEN EVOLUTION: CRIBIER-EDWARDS, EDWARDS SAPIEN, SAPIEN XT AND SAPIEN 3}

The TAVI clinical experience began with the Cribier-Edwards balloon-expandable valve (Edwards Lifesciences), which consisted of equine pericardium and a stainless steel frame ${ }^{1}$. Modification of this valve resulted in the Edwards SAPIEN valve, which also consisted of a stainless steel frame, but with bovine pericardial valve tissue and a fabric skirt made of polyethylene terephthalate (PET) in order to improve sealing. The RetroFlex delivery system (Edwards Lifesciences) accompanying this device was of large diameter (22$24 \mathrm{Fr}$ ) and associated with higher rates of vascular complications after TF implantation. The Edwards SAPIEN XT was then introduced with a cobalt-chromium stent frame, fewer and thinner struts and a low-profile NovaFlex delivery system (Edwards Lifesciences) to reduce vascular complications (Figure 2).

The SAPIEN 3 valve (Edwards Lifesciences) is the latest generation of the Edwards SAPIEN family and consists of a trileaflet pericardial bovine valve mounted in a cobalt-chromium stent with 


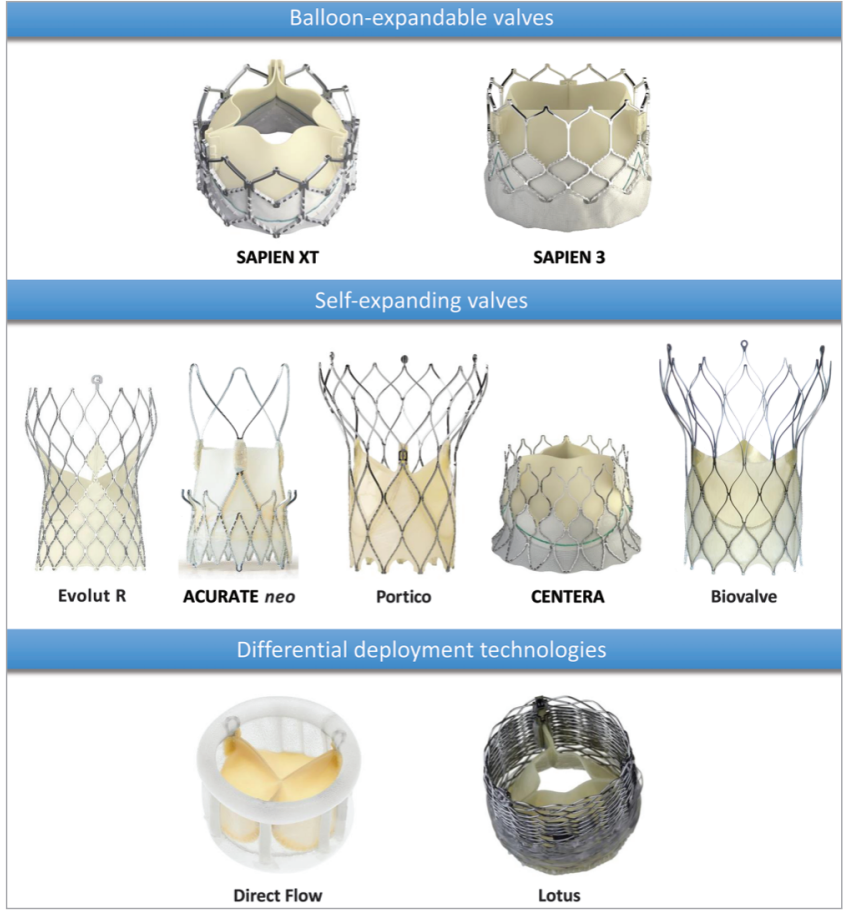

Figure 2. Current transfemoral TAVI devices. Pictures provided courtesy of Edwards Lifesciences, Irvine, CA, USA; Medtronic, Minneapolis, MN, USA; Symetis SA, Ecublens, Switzerland; St. Jude Medical, St. Paul, MN, USA; Biotronik AG, Bülach, Switzerland; Direct Flow Medical Inc., Santa Rosa, CA, USA and Boston Scientific, Marlborough, MA, USA.

an additional outer PET cuff to further enhance paravalvular sealing (Figure 2). The highly flexible, low-profile TF Commander delivery system (Edwards Lifesciences) has a distal short tapered tip to facilitate crossing of the native valve as well as additional features to facilitate valve alignment and positioning. The device is introduced through a 14/16 Fr expandable sheath (eSheath; Edwards Lifesciences), which transiently expands to accommodate the device before returning to its lower profile.

In a multicentre study of SAPIEN 3 valve implantations, rates of moderate paravalvular regurgitation at 30 days were as low as $3.5 \%$. TF implantation was associated with lower mortality and stroke rates as compared to alternative access (Table 1$)^{2}$. Studies comparing the outcomes of different generations of SAPIEN valves have been few and several analyses are ongoing (e.g., CHOICE Extend). In a propensity score-matched, single-centre analysis, SAPIEN 3 was associated with significantly lower rates of $\geq$ mild paravalvular regurgitation ( $15.9 \%$ versus $46.2 \%, \mathrm{p}=0.003$ ) before hospital discharge compared to SAPIEN XT. No differences in pacemaker rates $(9.8 \%$ versus $8.8 \%, \mathrm{p}=0.94$ ) and 30-day mortality (both $5 \%$ ) were observed ${ }^{3}$.

\section{Self-expanding valves}

These valves consist of biological cardiac valve tissue sewn inside a self-expanding nitinol-based stent frame, which is subsequently crimped inside a delivery capsule whose withdrawal results in valve deployment.

\section{THE COREVALVE EVOLUTION: COREVALVE AND EVOLUT R}

The CoreValve device (Medtronic) is the prototype of selfexpanding devices and consists of bovine (first-generation device, $25 \mathrm{Fr}$ delivery sheath) or porcine (second- and third-generation, $21 \mathrm{Fr}$ and $18 \mathrm{Fr}$ delivery sheaths, respectively) pericardial tissue mounted on a nitinol frame. The lower profiles of the newer-generation devices were achieved by switching to porcine pericardium and using a more flared outflow design. The stent frame consists of an inflow segment, a narrower supra-annular middle segment containing the leaflets, and an outflow segment with a cell design that allows blood flow and catheter access to the coronary ostia. A delivery catheter modification employed the low-profile AccuTrak $^{\text {TM }}$ delivery system (Medtronic) with features to reduce frictional forces during valve deployment.

The CoreValve Evolut RTM (Medtronic) is the latest in the family of CoreValve devices and has several modifications that make it repositionable, resheathable and recapturable. It is shorter in height than its predecessor but retains the $12 \mathrm{~mm}$ height of the pericardial skirt (Figure 2). Additionally, leaflets are treated with alpha-amino oleic acid, which binds to aldehyde groups within the pericardial tissue to inhibit calcification. The valve comes with its own $\mathrm{EnVeo}^{\mathrm{TM}}$ $\mathrm{R}$ delivery system (Medtronic), a very low-profile sheath (14 Fr equivalent) and the promise of first-time deployment accuracy ${ }^{4}$.

\section{THE PORTICO VALVE}

The Portico ${ }^{\text {TM }}$ device (St. Jude Medical, St. Paul, MN, USA) is a resheathable, repositionable and retrievable prosthesis consisting of bovine pericardial tissue and a nitinol frame (Figure 2). The inflow portion is made of porcine pericardium and functions as a sealing cuff while the leaflets are placed at the annular position close to the ventricular end. A lower leaflet profile and a more vertical ventricular stent end minimise left ventricular outflow tract protrusion and reduce the risk of conduction disturbances. The large open cell design of the stent frame preserves coronary flow and access. A feasibility study in 10 patients showed no incidence of stroke, new pacemaker implantation or death at 30 days after implantation and only one patient with moderate aortic regurgitation ${ }^{5}$.

\section{THE ACURATE NEO VALVE}

The ACURATE neo ${ }^{\text {TM }}$ (Symetis, Ecublens, Switzerland) device consists of a porcine aortic root valve and a nitinol frame with an hourglass shape containing three stabilisation arches which self-position the device during a "top-down" 3-step deployment (Figure 2). The valve leaflets are placed in a supra-annular position in the upper crown segment of the stent and the annular portion of the valve has a PET sealing skirt to reduce paravalvular regurgitation (refer to Table 1 for clinical results) ${ }^{6}$.

\section{THE CENTERA VALVE}

The CENTERA valve (Edwards Lifesciences) is a self-expanding, ultra low-profile valve composed of a nitinol frame and bovine pericardium, which can be delivered by a single operator using a $14 \mathrm{Fr}$ motorised delivery system. The stent frame is shorter than other 
self-expanding valves, and the ventricular end is flared to reduce left ventricular protrusion (Figure 2). The flaring of the ventricular portion was reduced in subsequent models because of increased conduction disturbances observed in early studies ${ }^{7}$. Unlike other self-expanding valves, the CENTERA valve is not functional until fully deployed and therefore requires rapid ventricular pacing at the time of implantation. The CE-mark approval study is ongoing.

\section{THE BIOVALVE}

The resheathable and repositionable Biovalve (Biotronik AG, Bülach, Switzerland) features a porcine pericardial valve mounted on a nitinol stent and is delivered through an 18 Fr delivery system with a single user-friendly component for positioning, resheathing and valve release (Figure 2). The valve has larger stent cell size in its outflow portion to facilitate coronary access. Implantation feasibility and short-term safety were demonstrated in the recently published BIOVALVE-1 study ${ }^{8}$.

\section{Differential deployment technologies THE LOTUS VALVE}

The Lotus ${ }^{\mathrm{TM}}$ valve (Boston Scientific, Marlborough, MA, USA) consists of bovine pericardial valve tissue mounted on a braided nitinol stent with an outer adaptive seal (Figure 2). The valve is pre-attached to the delivery system, which has two controls (a control knob and a release collar). The control knob facilitates complete repositioning and redeployment prior to final release, which is achieved by activation of the release collar. Valve deployment is achieved by mechanical expansion utilising the interaction of posts and buckles that are connected to the inner catheter of the delivery system. In the REPRISE II trial, device success was nearly $100 \%$ with only one patient having moderate aortic regurgitation at 30 days ${ }^{9}$. High rates of new pacemaker implantation were attributed to device oversizing as a consequence of availability in only two sizes (23 and $27 \mathrm{~mm}$ ).

\section{THE DIRECT FLOW MEDICAL VALVE}

The Direct Flow Medical ${ }^{\circledR}$ valve (Direct Flow Medical, Santa Rosa, CA, USA) is a non-metallic valve consisting of bovine pericardial tissue mounted over an inflatable two-ring structure covered with polyester fabric (Figure 2). These rings are able to adapt their shape to the native aortic annulus in order to prevent paravalvular regurgitation and can also be deflated to reposition the prosthesis if required. Once optimal positioning is achieved, an epoxy-based curing polymer is used to fill the structure, which subsequently solidifies to provide permanent support and position. The device may be difficult to position in patients with extensive outflow tract calcification. Safety and performance were evaluated in the DISCOVER trial where freedom from mortality and adverse events at 30 days were $99 \%$ and $91 \%$, respectively ${ }^{10}$.

\section{Comparison studies of devices with different designs}

A plethora of TAVI devices is now available as a result of rapid technological evolution, each with its own advantages and clinical outcomes. As a consequence, it is now essential to obtain data comparing the available devices in order to guide appropriate device selection.

To date, the CHOICE trial is the only randomised head-tohead study comparing balloon- and self-expandable TAVI ${ }^{11}$. In this investigator-initiated trial, the use of a balloon-expandable device resulted in a significantly higher rate of device success and a lower rate of moderate or severe paravalvular regurgitation. The need for a new pacemaker was also lower in the balloonexpandable group at 30 days. At one-year follow-up, there were no significant differences between the two groups with regard to mortality (cardiovascular or all-cause), stroke and repeat hospitalisation for heart failure. More than mild paravalvular regurgitation was more frequent in the self-expanding group, as observed at 30 days. Of concern, four patients in the balloon-expandable group had probable valve thrombosis as opposed to none in the self-expanding group ${ }^{12}$.

These key findings have been replicated in several recent publications from multicentre registries. Six-year follow-up data on 3,980 TAVI procedures performed in the United Kingdom from 2007-2012 showed no difference in survival at any time point between SAPIEN and CoreValve devices ${ }^{13}$. Use of the selfexpanding CoreValve device was associated with a significantly higher incidence of aortic regurgitation and need for pacemaker implantation. Similarly, in a recent meta-analysis comparing the valve types, self-expanding valve implantation was associated with a significantly higher incidence of new pacemaker implantation, $\geq 2+$ aortic regurgitation at 30 days, valve embolisation, and the need for $>1$ valve, although one-year mortality was similar with both self-expanding and balloon-expandable valves following TAVI via the TF approach ${ }^{14}$.

There are currently no published randomised trials comparing newer-generation devices. In a matched comparison of high surgical risk patients undergoing TAVI, use of the mechanically expanded Lotus valve was associated with higher rates of device success compared with the self-expanding CoreValve, a finding driven principally by higher rates of correct anatomic positioning and lower rates of moderate paravalvular regurgitation ${ }^{15}$. Cardiovascular mortality ( $0 \%$ for Lotus versus $4 \%$ ), and rates of major stroke (4\% for Lotus versus $2 \%$ ) and permanent pacemaker insertion ( $28 \%$ for Lotus versus $18 \%$ ) did not differ at 30 days (all $\mathrm{p}=\mathrm{NS}$ ). In a non-randomised trial comparing Lotus and SAPIEN 3 valves, post-procedural and other 30-day outcomes were similar with the two devices. There were no cases of more than mild aortic regurgitation with both devices. However, the Lotus valve was associated with a significantly higher need for permanent pacemaker implantation $(26.9 \%$ versus $3.8 \%$ for SAPIEN 3, $\mathrm{p}<0.003)^{16}$. Several randomised head-to-head approval trials are currently underway in the USA.

\section{Conclusion}

TAVI is an established alternative to surgery in inoperable and high-risk patients with severe aortic stenosis and a wide range 
of devices is now available. In recent years, TAVI technology has undergone rapid innovation, with development of devices specifically designed to address previous concerns regarding paravalvular regurgitation, conduction disturbances and vascular complications. Refinements of the design and features of the new prostheses include improved annular conformability, better valve sealing, and repositionability, which have virtually eliminated many of the limitations of first-generation devices. Preliminary data with these new devices are encouraging, although clinical experience is limited and long-term data are required before TAVI can be routinely offered to low- and intermediate-risk subjects.

\section{Conflict of interest statement}

M. Abdel-Wahab and G. Richardt have received institutional research grants from St. Jude Medical and Biotronik. M. AbdelWahab is a proctor for Boston Scientifc. G. Richardt receives lecture fees from Edwards Lifesciences and Boston Scientific. J. Jose is currently supported by an EAPCI grant in Interventional Cardiology which is partially sponsored by Medtronic.

\section{References}

1. Cribier A, Eltchaninoff H, Bash A, Borenstein N, Tron C, Bauer F, Derumeaux G, Anselme F, Laborde F, Leon MB. Percutaneous transcatheter implantation of an aortic valve prosthesis for calcific aortic stenosis: first human case description. Circulation. 2002;106:3006-8.

2. Webb J, Gerosa G, Lefèvre T, Leipsic J, Spence M, Thomas M, Thielmann M, Treede H, Wendler O, Walther T. Multicenter evaluation of a next-generation balloon-expandable transcatheter aortic valve. J Am Coll Cardiol. 2014;64:2235-43.

3. Nijhoff F, Abawi M, Agostoni P, Ramjankhan FZ, Doevendans PA, Stella PR. Transcatheter aortic valve implantation with the new balloon-expandable Sapien 3 versus Sapien XT valve system: a propensity score-matched single-center comparison. Circ Cardiovasc Interv. 2015;8:e02408.

4. Meredith IT. 6-month outcomes following TAVI with a novel repositionable self-expanding bioprosthesis. Presented at EuroPCR 2015, Paris, France.

5. Willson AB, Rodès-Cabau J, Wood DA, Leipsic J, Cheung A, Toggweiler S, Binder RK, Freeman M, DeLarochellière R, Moss R, Nombela-Franco L, Dumont E, Szummer K, Fontana GP, Makkar R, Webb JG. Transcatheter aortic valve replacement with the St. Jude Medical Portico valve: first-in-human experience. J Am Coll Cardiol. 2012;60:581-6.

6. Grube E. ACURATE neo TF trials: data and ongoing studies. Presented at EuroPCR 2014, Paris, France.

7. Binder RK, Schäfer U, Kuck KH, Wood DA, Moss R, Leipsic J, Toggweiler S, Freeman M, Ostry AJ, Frerker C, Willson AB, Webb JG. Transcatheter aortic valve replacement with a new self-expanding transcatheter heart valve and motorized delivery system. JACC Cardiovasc Interv. 2013;6:301-7.
8. Treede H, Lubos E, Conradi L, Deuschl F, Asch FM, Weissman NJ, Schofer N, Schirmer J, Koschyk D, Blankenberg S, Reichenspurner H, Schaefer U. Thirty-day VARC-2 and performance data of a new self-expanding transcatheter aortic heart valve. EuroIntervention. 2015 May 20. [Epub ahead of print].

9. Meredith IT, Walters DL, Dumonteil N, Worthley SG, Tchétché D, Manoharan G, Blackman DJ, Rioufol G, HildickSmith D, Whitbourn RJ, Lefèvre T, Lange R, Müller R, Redwood S, Allocco DJ, Dawkins KD. Transcatheter aortic valve replacement for severe symptomatic aortic stenosis using a repositionable valve system: 30-day primary endpoint results from the REPRISE II study. J Am Coll Cardiol. 2014;64:1339-48.

10. Schofer J, Colombo A, Klugmann S, Fajadet J, DeMarco F, Tchétché D, Maisano F, Bruschi G, Latib A, Bijuklic K, Weissman N, Low R, Thomas M, Young C, Redwood S, Mullen M, Yap J, Grube E, Nickenig G, Sinning JM, Hauptmann KE, Friedrich I, Lauterbach M, Schmoeckel M, Davidson C, Lefevre T. Prospective multicenter evaluation of the direct flow medical transcatheter aortic valve. J Am Coll Cardiol. 2014;63:763-8.

11. Abdel-Wahab M, Mehilli J, Frerker C, Neumann FJ, Kurz T, Tölg R, Zachow D, Guerra E, Massberg S, Schäfer U, El-Mawardy M, Richardt G; CHOICE investigators. Comparison of balloon-expandable vs self-expandable valves in patients undergoing transcatheter aortic valve replacement: the CHOICE randomized clinical trial. JAMA. 2014;311:1503-14.

12. Abdel-Wahab M, Neumann FJ, Mehilli J, Frerker C, Richardt D, Landt M, Jose J, Tölg R, Kuck KH, Massberg S, Robinson DR, El-Mawardy M, Richardt G; CHOICE Investigators. 1-Year Outcomes After Transcatheter Aortic Valve Replacement With Balloon-Expandable Versus Self-Expandable Valves: Results From the CHOICE Randomized Clinical Trial. J Am Coll Cardiol. 2015;66:791-800.

13. Ludman PF, Moat N, de Belder MA, Blackman DJ, Duncan A, Banya W, MacCarthy PA, Cunningham D, Wendler O, Marlee D, Hildick-Smith D, Young CP, Kovac J, Uren NG, Spyt T, Trivedi U, Howell J, Gray H. Transcatheter aortic valve implantation in the United Kingdom: temporal trends, predictors of outcome and 6-year follow-up: a report from the UK TAVI Registry 2007 to 2012. Circulation. 2015;131:1181-90.

14. Agarwal S, Parashar A, Kumbhani DJ, Svensson LG, Krishnaswamy A, Tuzcu EM, Kapadia SR. Comparative meta-analysis of balloon-expandable and self-expandable valves for transcatheter aortic valve replacement. Int J Cardiol. 2015;197:87-97.

15. Gooley RP, Talman AH, Cameron JD, Lockwood SM, Meredith IT. Comparison of Self-Expanding and Mechanically Expanded Transcatheter Aortic Valve Prostheses. JACC Cardiovasc Interv. 2015;8:962-71.

16. Wöhrle J, Gonska B, Rodewald C, Trepte U, Koch S, Scharnbeck D, Seeger J, Markovic S, Rottbauer W. Transfemoral aortic valve implantation with the repositionable Lotus valve compared with the balloon-expandable Edwards Sapien 3 valve. Int $J$ Cardiol. 2015;195:171-5. 